\title{
Cadmium, Lead, Copper and Zinc in Breast Milk in Poland
}

\author{
Anna Winiarska-Mieczan
}

Received: 23 August 2013 / Accepted: 27 November 2013 / Published online: 12 December 2013

(C) The Author(s) 2013. This article is published with open access at Springerlink.com

\begin{abstract}
Mother's milk is the fundamental food for infants. It contains proteins, fat, carbohydrates and essential metals which are necessary to ensure correct functioning of the organism. Unfortunately, breast milk is a potential source of toxic metals, which are dangerous for a baby. In Poland, previous research concerning the content of metals in breast milk was very scarce or its results were unavailable. The present study aimed at assessing the content of $\mathrm{Cd}, \mathrm{Pb}, \mathrm{Cu}$ and $\mathrm{Zn}$ in human breast milk, as well as estimating the mean weekly intake of these metals by breast-fed infants from Poland. The average concentrations of $\mathrm{Cd}, \mathrm{Pb}, \mathrm{Cu}$ and $\mathrm{Zn}$ were $2.114 \mu \mathrm{g} / \mathrm{l}, 6.331 \mu \mathrm{g} / \mathrm{l}, 0.137 \mathrm{mg} / \mathrm{l}$ and $1.623 \mathrm{mg} / \mathrm{l}$, respectively. The admissible levels of supply of these toxic metals has not been exceeded, but their contents were high, particularly in 6-month-old infants (nearly $85 \%$ TWI for $\mathrm{Cd}$ and nearly $70 \% \mathrm{BMDL}_{01}$ for $\mathrm{Pb}$ ). The daily intake of $\mathrm{Cu}$ and $\mathrm{Zn}$ did not fully satisfy the infant's requirements determined by Polish standards and WHO recommendations. Since the lifestyle of lactating women has a direct influence on the content of these elements in breast milk, women should be educated in this respect with particular focus on eliminating tobacco smoking, both by breastfeeding mothers and by their direct environment.
\end{abstract}

Keywords Breast milk · Infant - Cadmium · Lead · Zinc . Copper · Intake

\section{Introduction}

Breastfeeding is the best method of nutrition for infants. The World Health Organisation (WHO) recommends breastfeeding as the exclusive method of nutrition for newborns and infants at

\footnotetext{
A. Winiarska-Mieczan $(\bowtie)$

Department of Bromatology and Food Physiology, University of Life

Sciences in Lublin, Akademicka 13, 20-950 Lublin, Poland

e-mail: anna.mieczan@up.lublin.pl
}

least up to 6 months of age [1]. Previous research by this author [2] carried out in the region of Lublin (eastern Poland) demonstrated that as many as $87 \%$ of women were breastfeeding for at least 6 months. The components of mother's milk, such as lactoferrin, lysozyme and $\alpha$-lactalbumin, create a barrier protecting the baby against harmful environmental factors, enhancing the body's defence mechanisms and stimulating the development of the immune system [3]. Breast milk also has an influence on the development of intestinal microflora [3] and structural and functional maturity of mucous membranes and reduces the risk of allergies and autoimmune diseases [4]. However, mother's milk can also be a source of cadmium $(\mathrm{Cd})$ and lead $(\mathrm{Pb})$ for a baby. The content of these elements in breast milk reflects the level of environmental pollution and the mother's diet [5-8]. The presence of these metals in food products has become a global problem [5, 9, 10]. In Poland, the highest content of $\mathrm{Cd}$ and $\mathrm{Pb}$ is found in food derived from plants including but not limited to vegetables, in particular, potatoes, and grains and cereals [11]. Mothers who smoked tobacco create an additional source of toxic trace elements in the body, thus increasing the content of $\mathrm{Cd}$ and $\mathrm{Pb}$ in the breast milk [12, 13]. Research by Öhrvik et al. [14] revealed that $\mathrm{Cd}$ leads to a dysfunction of the mammary glands in mice, which is the reason for developmental disorders among sucklings. Since 'heavy metals' is a poor scientific term [15], in the present study, the term 'toxic metals' is used with reference to $\mathrm{Cd}$ and $\mathrm{Pb}$, and 'essential metals' with reference to copper $(\mathrm{Cu})$ and zinc $(\mathrm{Zn})$.

The cycle of metals in the environment is linked with the food chain: soil-plant-animal-man. The transfer of toxic metals to the higher link results in a cumulative increase in their content [16]. Cd is primarily deposited in the liver and kidneys, but in infants, it poses the greatest hazard to their dynamically developing nervous system, also affecting boneformation processes, and is a significant carcinogen [17-20]. Tests on rats demonstrate that $\mathrm{Cd}$ supplied with milk affects the serotonin level in the brain of a growing animal [21]. The highest $\mathrm{Cd}$ accumulation levels are recorded during the first 
3 years of human life [22]. In children, it can inhibit intellectual development and causes anaemia and rickets [23]. Significantly, a positive correlation between the concentration of $\mathrm{Cd}$ and $\mathrm{Pb}$ in children and the occurrence of autism has been observed [16]. Neurological effects of Pb observed in children include motor skills disorder and behavioural problems [24]. Exposure to this metal for several years after birth is particularly detrimental to the future intellectual potential of children $[2,25]$. Children are exposed to accumulation of $\mathrm{Pb}$ due to a slower excretion process and lower body weight and also because of reduced immunity [26].

Essential metals, such as $\mathrm{Cu}$ and $\mathrm{Zn}$, are necessary to ensure the correct functioning of the body but, in excessive amounts, have a harmful effect [27]. $\mathrm{Cu}$ is an element necessary for synthesising haemoglobin, forming myelin sheaths in the nervous system, and for bone tissue formation processes [27, 28]. $\mathrm{Zn}$ is an important element at the foetal stage [27]. A deficit of this element can lead to defects in the nervous system and cause retardation of the foetus' growth and development [29].

In Poland, previous research concerning the content of $\mathrm{Pb}$, $\mathrm{Cd}, \mathrm{Cu}$ and $\mathrm{Zn}$ in breast milk was very scarce or its results were unavailable. No detailed evaluations of the effect of age and lifestyle of Polish women on the content of metallic elements in breast milk are available. The study is aimed to evaluate the content of $\mathrm{Cd}, \mathrm{Pb}, \mathrm{Cu}$ and $\mathrm{Zn}$ in their breast milk and to estimate the intake of these metals by breastfed infants.

\section{Materials and Methods}

\section{Materials}

Breast milk samples $(\sim 25 \mathrm{ml})$ were collected by manual expression from 320 healthy lactating women from the Lublin region (eastern Poland) during 7 days of sampling. All women were informed about the purpose of the study and voluntarily consented to provide breast milk samples for analysis. Contact with the subjects was established during the medical check-up of their children in paediatric clinics.

The samples were collected in the period from August to December 2010. Each sample was sealed in a polyethylene bag and frozen at $-20^{\circ} \mathrm{C}$ for further analysis.

\section{Methods}

The breast milk samples were shaken manually before the analysis. Also, three samples were taken $(2 \mathrm{ml})$ from each of the bags. Samples were dried at $65^{\circ} \mathrm{C}$ for $12 \mathrm{~h}$, next at $105^{\circ} \mathrm{C}$ for $24 \mathrm{~h}$, and mineralised in a muffle furnace. The samples were treated by dry mineralisation at a temperature of $4500^{\circ} \mathrm{C}$ for $12 \mathrm{~h}$, and the ash obtained was suffused with $2 \mathrm{ml}$ of hydrogen peroxide, evaporated until dry and once more burnt at a temperature of $450^{\circ} \mathrm{C}$ for $12 \mathrm{~h}$. Ashed samples were diluted in spectrally pure $1 \mathrm{M} \mathrm{HNO}_{3}$. The content of $\mathrm{Cd}$ and $\mathrm{Pb}$ was determined by GF AAS technique in a Varian Spectr AA 880 apparatus, including atomisation in a graphite furnace and using the Zeeman background correction. Argon was used as the pure gas. The content of $\mathrm{Cd}$ was determined at $\lambda=$ $228.8 \mathrm{~nm}$, with $4 \mathrm{~mA}$ and $0.5 \mathrm{~nm}$ spectral bandpass (LOD $0.01 \mathrm{mg} / \mathrm{kg}$, LOQ $0.02 \mathrm{mg} / \mathrm{kg}$ ). The deviation of duplicate measurement was below $5.3 \%$. The content of $\mathrm{Pb}$ was determined at wavelength $\lambda=217.0 \mathrm{~nm}$, with $10 \mathrm{~mA}$ and $1 \mathrm{~nm}$ spectral bandpass (LOD $0.209 \mathrm{mg} / \mathrm{kg}$, LOQ $0.419 \mathrm{mg} / \mathrm{kg}$ ). The content of $\mathrm{Zn}$ and $\mathrm{Cu}$ was determined using the FAAS flame technique in a Varian SpectrAA $280 \mathrm{FS}$ apparatus (with SPS3 autosampler). Zn was detected at $\lambda=213.9 \mathrm{~nm}$, with $5 \mathrm{~mA}$ and $1 \mathrm{~nm}$ spectral bandpass (LOD $0.01 \mathrm{mg} / \mathrm{kg}$, LOQ $0.02 \mathrm{mg} / \mathrm{kg}), \mathrm{Cu}$ at $\lambda=324.8 \mathrm{~nm}$, with $4 \mathrm{~mA}$ and $0.5 \mathrm{~nm}$ spectral bandpass (LOD $0.013 \mathrm{mg} / \mathrm{kg}$, LOQ $0.016 \mathrm{mg} / \mathrm{kg}$ ). In order to make the calibration line, standard solutions of $\mathrm{Cd}$, $\mathrm{Pb}, \mathrm{Zn}$ and $\mathrm{Cu}$ were procured from Merck (Germany). A series of solutions of varying concentrations were prepared for all the examined ions by diluting the standards: $0.00,0.10$, $0.20,0.40,1.00$ and $2.00 \mathrm{ng} / \mathrm{ml}$. Quality control of analytical measurements was performed using blank samples and certified reference materials: IRMM-804 Rice Flour $(\mathrm{Cd})$ and BCR-063R Skimmed Milk Powder ( $\mathrm{Pb}, \mathrm{Zn}$ and $\mathrm{Cu})$. The certified reference materials contained $\mathrm{Cd} 1.16 \mathrm{mg} / \mathrm{g}, \mathrm{Pb}$ $0.815 \mathrm{mg} / \mathrm{g}, \mathrm{Zn} 49.0 \mu \mathrm{g} / \mathrm{g}$ and $\mathrm{Cu} 0.602 \mu \mathrm{g} / \mathrm{g}$. The mean recovery rate of $\mathrm{Cd}$ from the reference materials was $96 \%$, of $\mathrm{Pb} 95 \%$, of $\mathrm{Zn} 117 \%$ and of $\mathrm{Cu} 121 \%$.

\section{Calculation of Metals Intake}

The mean intake of $\mathrm{Cd}, \mathrm{Pb}, \mathrm{Cu}$ and $\mathrm{Zn}$ in breast milk was calculated for infants aged 1, 3, 6 and 12 months. Since it is difficult to calculate the daily intake of milk by a breast-fed infant, the supply of powdered milk, as recommended in Poland, was used as a reference value [30]. The calculation of the tolerable intake of toxic metals was based on mean infant body weight (Table 1). The tolerable weekly intake (TWI) for Cd was determined at $2.5 \mu \mathrm{g} / \mathrm{kg}$ of body weight/ week [31]. The benchmark dose lower confidence limit $\left(\mathrm{BMDL}_{01}\right)$ for $\mathrm{Pb}$ was determined at $0.5 \mu \mathrm{g} / \mathrm{kg}$ of body weight/day (3.5 $\mu \mathrm{g} / \mathrm{kg}$ of body weight/week) [32].

\section{Statistical Analysis}

The results were analysed using statistical methods. Arithmetic mean values, standard deviation (SD), median, maximum and minimum values and percentile values (25 and 75$)$ were calculated using STATISTICA 6.0 software. The $p$ values $<$ 0.05 were considered significant. Full factorial analysis of variance (ANOVA) was used to test for significant effects of the women's age, stage of lactation and tobacco smoking on 
Table 1 Average body weight of infants from Poland and daily milk consumption

\begin{tabular}{|c|c|c|c|c|}
\hline & \multicolumn{4}{|c|}{ Age of children } \\
\hline & 1 month & 3 months & 6 months & 12 months \\
\hline Average body weight ${ }^{\mathrm{a}}$ relevant for Poland, $\mathrm{g}$ & 4,500 & 6,250 & 7,750 & 10,500 \\
\hline Daily consumption of milk ${ }^{\mathrm{b}}, \mathrm{ml}$ & 700 & 780 & 900 & 660 \\
\hline
\end{tabular}

${ }^{a}$ The average body weight relevant for Poland was estimated according to a centile chart for infants. The values for boys and girls were averaged

${ }^{b}$ The supply of milk formulas, as recommended in Poland, was used as a reference value, adopter from Ref. [30]

$\mathrm{Cd}, \mathrm{Pb}, \mathrm{Cu}$ and $\mathrm{Zn}$ levels in breast milk. The significance of differences between mean values was estimated using Tukey's test.

\section{Profile of the Analysed Population of Women}

During the first meeting the women were interviewed to determine the profile of the studied population (age, number of lactations, period of current lactation). The questions also concerned exposure of the women to factors likely to affect the content of toxic metals in milk (occupational exposure, smoking). The data was presented in Table 2.

\section{Results}

\section{Content of $\mathrm{Cd}$ and $\mathrm{Pb}$ in the Breast Milk}

Table 3 presents the content of $\mathrm{Cd}, \mathrm{Pb}, \mathrm{Cu}$ and $\mathrm{Zn}$ covered by the research in the breast milk and effects of women's age. The average content of $\mathrm{Cd}$ in the milk slightly exceeded $2 \mu \mathrm{g} / \mathrm{l}$ (0.215-7.355), while that of $\mathrm{Pb}$ amounted to $6.3 \mu \mathrm{g} / \mathrm{l}(0.486$ 12.01). The highest content of $\mathrm{Cd}$ was found in the breast milk of women aged 31 to 35 (more than $3 \mu \mathrm{g} / \mathrm{l}$ ), while most $\mathrm{Pb}$ was discovered in the breast milk of women aged 36 to 40 and 26 to 30 (approx. 7-7.4 $\mu \mathrm{g} / \mathrm{l}$ ). The lowest content of both $\mathrm{Cd}$ and $\mathrm{Pb}$ was characteristic of the milk of women aged 20 to 25 .
Table 2 The profile of the analysed population of women

\begin{tabular}{|c|c|c|c|c|c|}
\hline & \multicolumn{4}{|c|}{ Age of mothers, years } & \multirow[t]{2}{*}{ Total } \\
\hline & $20-25$ & $26-30$ & $31-35$ & $36-40$ & \\
\hline Number of women & 35 & 158 & 70 & 60 & 323 \\
\hline \multicolumn{6}{|l|}{ Place of residence } \\
\hline Village & 25 & 59 & 30 & 9 & 123 \\
\hline City $<25,000$ habitants & 10 & 28 & 22 & 0 & 60 \\
\hline City $>25,000$ habitants & 0 & 71 & 18 & 51 & 140 \\
\hline \multicolumn{6}{|l|}{ Number of lactation } \\
\hline I & 35 & 143 & 25 & 10 & 213 \\
\hline II & 0 & 15 & 45 & 0 & 60 \\
\hline III & 0 & 0 & 0 & 40 & 40 \\
\hline IV & 0 & 0 & 0 & 10 & 10 \\
\hline \multicolumn{6}{|l|}{ Lactation stage } \\
\hline 1 month & 0 & 40 & 10 & 9 & 59 \\
\hline $2-3$ months & 11 & 52 & 9 & 36 & 108 \\
\hline 4-6 months & 14 & 36 & 36 & 0 & 86 \\
\hline $7-12$ months & 10 & 30 & 15 & 15 & 70 \\
\hline \multicolumn{6}{|l|}{ Smoking habit } \\
\hline Current smoker & 0 & 20 & 20 & 0 & 40 \\
\hline Past smoker & 0 & 23 & 0 & 3 & 26 \\
\hline Never & 35 & 115 & 50 & 57 & 257 \\
\hline \multicolumn{6}{|l|}{ Passive smoking } \\
\hline Yes & 12 & 34 & 8 & 7 & 61 \\
\hline No & 23 & 124 & 62 & 53 & 262 \\
\hline Occupational exposure to $\mathrm{Cd}$ or $\mathrm{Pb}$ & 0 & 0 & 0 & 0 & 0 \\
\hline
\end{tabular}


Table 3 Content of $\mathrm{Cd}, \mathrm{Pb}, \mathrm{Cu}$, and $\mathrm{Zn}$ in the breast milk and effect of the mother's age, $\mu \mathrm{g} / 1$

\begin{tabular}{llllll}
\hline Age of mothers, years & $n$ & $\mathrm{Cd}$ & $\mathrm{Pb}$ & $\mathrm{Cu}$ & $\mathrm{Zn}$ \\
\hline $20-25$ & 35 & $0.723^{\mathrm{a}}$ & $4.762^{\mathrm{a}}$ & $0.088^{\mathrm{a}}$ & $0.701^{\mathrm{a}}$ \\
$26-30$ & 158 & $2.151^{\mathrm{b}}$ & $6.932^{\mathrm{c}}$ & $0.154^{\mathrm{c}}$ & $2.504^{\mathrm{c}}$ \\
$31-35$ & 70 & $3.031^{\mathrm{d}}$ & $6.221^{\mathrm{b}}$ & $0.137^{\mathrm{b}}$ & $1.674^{\mathrm{b}}$ \\
$36-40$ & 60 & $2.552^{\mathrm{c}}$ & $7.411^{\mathrm{d}}$ & $0.169^{\mathrm{d}}$ & $1.612^{\mathrm{b}}$ \\
Mean & & 2.114 & 6.331 & 0.137 & 1.623 \\
Standard deviation & & 2.112 & 4.614 & 0.092 & 1.763 \\
Minimum value & & 0.215 & 0.486 & 0.025 & 0.043 \\
Maximum value & & 7.355 & 12.01 & 0.455 & 8.160 \\
Median & & 1.260 & 1.951 & 0.106 & 1.240 \\
25th percentile & & 0.557 & 1.602 & 0.069 & 0.448 \\
75th percentile & & 3.017 & 9.188 & 0.158 & 1.941 \\
Effects of women's age & & $p<0.05$ & $p<0.05$ & $p<0.05$ & $p<0.05$ \\
\hline
\end{tabular}

a,b,c,d In the same column, values with different superscripts differ significantly $(p<0.05)$

The stage of lactation had a significant effect on the content of Cd (ANOVA; $F=9.76 ; p<0.05$ ) and Pb (ANOVA; $F=$ $2.35 ; p<0.05$ ) in the breast milk (Fig. 1). The highest content of Cd was characteristic of breast milk between 4 and 6 months of lactation $(2.94 \mu \mathrm{g} / \mathrm{l})$, while the lowest value was recorded for the first month's milk, i.e. the colostrum (less than $1.7 \mu \mathrm{g} /$ 1). The highest content of $\mathrm{Pb}$ was found in milk between 2 and 3 months of lactation (nearly $3.3 \mu \mathrm{g} / \mathrm{l}$ ), while it was definitely lower in milk between 7 and 12 months of lactation (less than $2 \mu \mathrm{g} / \mathrm{l})$.

Figure 2 presents the mean weekly intake of metals by the infant in the first, third, sixth and 12th months of life per
$1 \mathrm{~kg}$ of body weight. The results were calculated based on the mean content of the analysed components in milk, depending on the stage of lactation. The body weight of an infant and the estimated daily intake of milk is presented in Table 1. Table 4 compares the $\%$ TWI and $\%$ BMDL $_{01}$ for infants aged 1, 3, 6 and 12 months with the average body weight recorded in Poland, assuming the value of $2.5 \mu \mathrm{g} \mathrm{Cd}$ [31] and $3.5 \mu \mathrm{g} \mathrm{Pb}$ [32] per $1 \mathrm{~kg}$ of body weight/week. It was determined that the admissible levels of $\mathrm{Cd}$ and $\mathrm{Pb}$ supply were not exceeded; they were elevated though. For $\mathrm{Cd}$, this was from $32.8 \%$ TWI (in 12-monthold babies) to $84.8 \%$ TWI (in 6-month-old infants), whereas for $\mathrm{Pb}$ from $23.9 \% \mathrm{BMDL}_{01}$ (in 12-month-old babies) to $84 \% \mathrm{BMDL}_{01}$ (in 1-month-old infants).

Figure 3 presents the content of $\mathrm{Cd}$ and $\mathrm{Pb}$ in the breast milk of smoking women compared to non-smokers. ANOVA indicated that this factor had a significant effect on the levels of $\mathrm{Cd}(F=27.08 ; p<0.05)$ and $\mathrm{Pb}(F=18.22 ; p<0.05)$. As expected, more toxic metals were found in the milk of women who smoked tobacco.

\section{Content of $\mathrm{Cu}$ and $\mathrm{Zn}$ in the Breast Milk}

The average content of $\mathrm{Cu}$ in the milk slightly exceeded $0.137 \mathrm{mg} / 1(0.025-0.455)$, while that of $\mathrm{Zn}$ amounted to $1.623 \mathrm{mg} / \mathrm{l}(0.043-8.160$; Table 3$)$. The highest content of $\mathrm{Cu}$ was recorded in the milk of women aged $26-30$ and $36-40$ (approx. 0.15-0.17 mg/l). The breast milk of women aged 2025 was found to contain half as much $\mathrm{Cu}$. The highest content of $\mathrm{Zn}$ was characteristic of the breast milk of women aged 2630 (more than $2.5 \mathrm{mg} / \mathrm{l}$ ), while the lowest value was recorded for the milk of mothers aged 20-25 aged (slightly above $0.7 \mathrm{mg} / \mathrm{l})$.
Fig. 1 Effects of the lactation stage (months) on $\mathrm{Cd}, \mathrm{Pb}, \mathrm{Cu}$ and $\mathrm{Zn}$ levels in breast milk, per $1 \mathrm{~L}$. a,b,c,d $p<0.05$
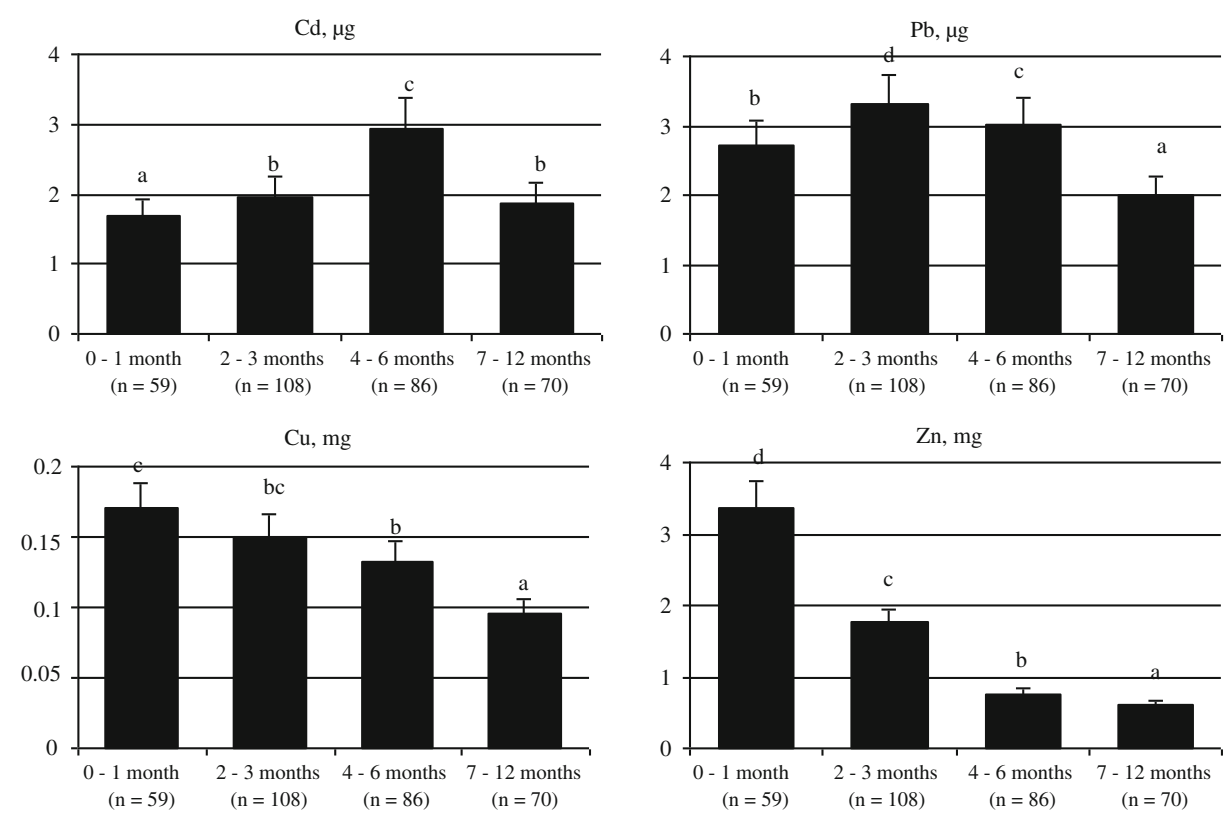
Fig. 2 Mean weekly intake of $\mathrm{Cd}, \mathrm{Pb}, \mathrm{Cu}$ and $\mathrm{Zn}$ from breast milk, per $1 \mathrm{~kg}$ of infant's body weight. ${ }^{\mathrm{a}, \mathrm{b}, \mathrm{c}, \mathrm{d}} p<0.05$
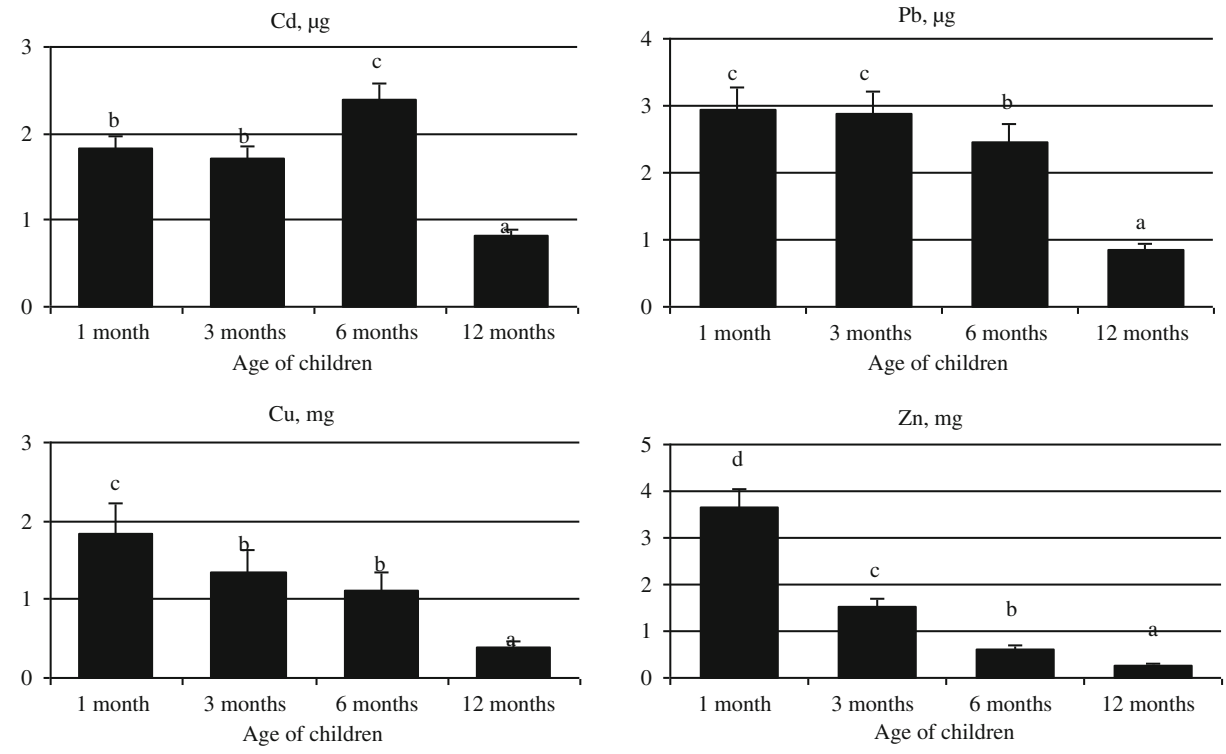

The content of $\mathrm{Cu}$ and $\mathrm{Zn}$ in breast milk was analysed depending on the stage of lactation (Fig. 1). The highest content of $\mathrm{Cu}$ was recorded in the breast milk of women in the first month of lactation $(0.17 \mathrm{mg} / \mathrm{l})$, while the lowest value of this element was noted in milk between 7 and 12 months of breastfeeding (less than $0.1 \mathrm{mg} / \mathrm{l}$ ). The highest content of $\mathrm{Zn}$ was also found in the first month's milk (more than $3.3 \mathrm{mg} / \mathrm{l}$ ), while the lowest value was recorded for milk between 7 and 12 months of lactation (approx. $0.61 \mathrm{mg} / \mathrm{l}$ ).

The calculated $\%$ of coverage of the infant's requirement of $\mathrm{Cu}$ and $\mathrm{Zn}$ supplied in mother's milk is presented in Table 5. It was revealed that the daily supply of $\mathrm{Cu}$ did not fully cover the infant's demand for this element determined in the Polish standard [33]. About $60 \%$ of the infants' requirement was covered during the first 6 months of life compared with less than $30 \%$ during the second 6 months. Breast milk in the first month of lactation was rich in $\mathrm{Zn}$-the supply of this element exceeded the infant's requirement by approximately $17 \%$.

Table $4 \%$ TWI (for $\mathrm{Cd}$ ) and $\% \mathrm{BMDL}_{01}$ (for $\mathrm{Pb}$ ) for infants aged 1, 3, 6, and 12 months with the average body weight relevant for Poland (see Table 1$), \mu \mathrm{g} / \mathrm{kg}$ of body weight/week

\begin{tabular}{lll}
\hline & $\mathrm{Cd}$ & $\mathrm{Pb}$ \\
\hline EFSA norm & $2.5 \mu \mathrm{g}[31]$ & $3.5 \mu \mathrm{g}[32]$ \\
Infant's age & $\% \mathrm{TWI}$ & $\% \mathrm{BMDL}_{01}$ \\
1 month & $72.72^{\mathrm{b}}$ & $84.00^{\mathrm{c}}$ \\
3 months & $67.70^{\mathrm{b}}$ & $82.37^{\mathrm{c}}$ \\
6 months & $84.84^{\mathrm{c}}$ & $69.91^{\mathrm{b}}$ \\
12 months & $32.84^{\mathrm{a}}$ & $23.89^{\mathrm{a}}$
\end{tabular}

${ }^{a, b, c}$ In the same column, values with different superscripts differ significantly, $p<0.05$
Afterwards, the concentration of this element decreased and after the first 6 months of life mother's milk covered only $20 \%$ of the $\mathrm{Zn}$ requirement.

\section{Discussion}

\section{Content of $\mathrm{Cd}, \mathrm{Pb}, \mathrm{Cu}$ and $\mathrm{Zn}$ in the Breast Milk}

The content of $\mathrm{Cd}$ and $\mathrm{Pb}$ in breast milk is a global problem. It is primarily related to the common presence of these toxic metals in the environment and thus inevitable exposure to their effect $[26,34]$. The present study showed no excessive admissible levels of toxic metals supply. However, the high content of $\mathrm{Cd}$ and $\mathrm{Pb}$ in milk consumed by infants at the age of 6 months is a disturbing fact since breast milk is not the only source of these metals for them. Research revealed that toxic metals are also present in other infant food, both in Poland [35] and in other countries [36, 37]. Admittedly, the studies referred above revealed no excessive standard limits; still, there is a risk of excessive supply of $\mathrm{Cd}$ and $\mathrm{Pb}$ in infants fed with breast milk and, at the same time, given complementary foods, particularly when in 2012 the admissible intake levels of $\mathrm{Cd}$ and $\mathrm{Pb}$ were radically reduced $[31,32]$. In Table 6 , the levels of $\mathrm{Cd}$ and $\mathrm{Pb}$ in breast milk recorded in this study were compared with those of other selected countries. The recorded Cd milk levels were considerably lower than those reported in Spain, Brazil and Nigeria and were higher than those of women from Sweden and Italy. The highest content of Cd - within the range of $0.6-1.3 \mu \mathrm{g} / \mathrm{l}$ - was recorded in the milk of mothers from Spain. The content of $\mathrm{Pb}$ resulting from the present study was comparable to data from Austria - the results referred to the maximum levels of $\mathrm{Pb}$ determined for 


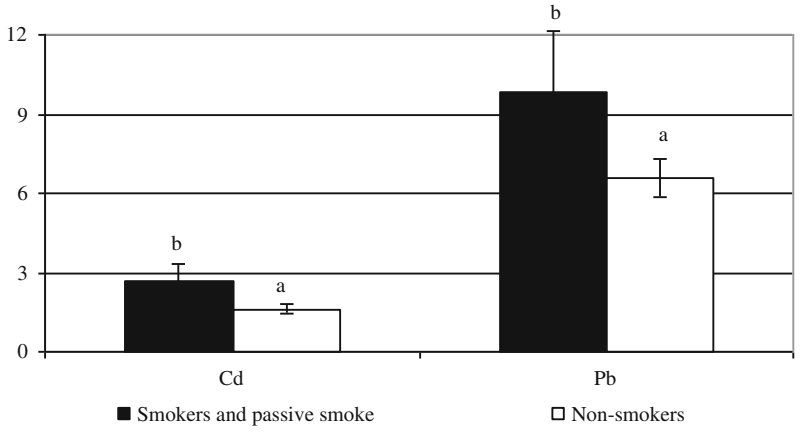

Fig. 3 Mean levels of $\mathrm{Cd}$ and $\mathrm{Pb}$ in breast milk of smoking and nonsmoking women, $\mu \mathrm{g} / 1$. ${ }^{\mathrm{a}, \mathrm{b}} p<0.05$

this country - and was significantly lower than in women from Spain, Iran, Saudi Arabia and China (Table 6).

Mandić et al. [38] found that the breast milk of Croatian women contained nine times more $\mathrm{Zn}$ than the milk analysed during the present study (Table 6). The content of $\mathrm{Zn}$ in the analysed samples amounted to $1-4.95 \mathrm{mg} / \mathrm{l}$. The highest content of $\mathrm{Zn}$ was recorded in the breast milk of women from Libya and the lowest in women from Venezuela [39]. According to Hannan et al. [39], the daily intake of $\mathrm{Cu}$ and $\mathrm{Zn}$ from the Libyan mothers' milk is higher than the recommended daily amount (RDA) value, whereas this study shows that the daily supply of $\mathrm{Cu}$ and $\mathrm{Zn}$ did not fully satisfy the infant's demand for those elements as defined by the Polish standard [33] and the WHO standard [40]. A low level of Cu causes no proven risk of nutritional deficiencies of $\mathrm{Cu}$ in the child during the first 6 months of lactation. Babies are born with hepatic reserves of $\mathrm{Cu}$ to balance low concentrations of these elements

Table 5 The calculated \% of coverage of an infant's requirement of $\mathrm{Cu}$ and $\mathrm{Zn}$ from breast milk

\begin{tabular}{lll}
\hline & $\mathrm{Cu}$ & $\mathrm{Zn}$ \\
\hline Polish norm, mg/day [33] & $\begin{array}{l}0.2-0.3 \\
\% \text { of Polish norm }\end{array}$ & 2.0 \\
& & \\
Infant's age & $59.39^{\mathrm{b}}$ & $117.6^{\mathrm{d}}$ \\
1 month & $60.18^{\mathrm{b}}$ & $68.52^{\mathrm{c}}$ \\
3 months & $61.69^{\mathrm{b}}$ & $34.43^{\mathrm{b}}$ \\
6 months & $29.11^{\mathrm{a}}$ & $20.13^{\mathrm{a}}$ \\
12 months & $0.33-0.62$ & $5.33-5.6$ \\
WHO norm, mg/day [40] & $\%$ of WHO norm & \\
& & \\
Infant's age & $36.00^{\mathrm{bc}}$ & $44.36^{\mathrm{d}}$ \\
1 month & $36.47^{\mathrm{c}}$ & $25.86^{\mathrm{c}}$ \\
3 months & $33.35^{\mathrm{b}}$ & $22.21^{\mathrm{b}}$ \\
6 months & $9.701^{\mathrm{a}}$ & $7.189^{\mathrm{a}}$ \\
12 months &
\end{tabular}

a,b,c,d In the same column, values with different superscripts differ significantly, $p<0.05$ in breast milk [41]. Additionally, $\mathrm{Zn}$ and $\mathrm{Cu}$ in breast milk are characterised by high bioavailability compared with infant milk formulas [42-44], and it may be supposed that the body's resources of these trace elements are sufficient for breast-fed babies. On the other hand, a low content of $\mathrm{Cu}$ is a condition for bacteriostatic properties of breast milk [45]. However, it must be remembered that mother's milk is the sole source of food for an infant only during the initial 5-6 months of life, so a deficiency of $\mathrm{Cu}$ and $\mathrm{Zn}$ after the first 6 months of life should not cause alarm since the infant is also supplied with this element in other food.

\section{Effects of Lactation Stage}

The present study findings suggest a relationship between the stage of lactation and the content of $\mathrm{Cd}$ and $\mathrm{Pb}$ in milk. Leotsinidis et al. [46] found that the colostrum of Greek women contained much more $\mathrm{Cd}$ and $\mathrm{Pb}(0.19$ and $0.48 \mu / 1)$ than the post-colostral milk $(0.14$ and $0.15 \mu / \mathrm{l})$. By contrast, in our study, the lowest value for $\mathrm{Cd}$ was recorded for the first month's milk.

The content of $\mathrm{Zn}$ and $\mathrm{Cu}$ in breast milk depends on the stage of lactation. Almeida et al. [47] recorded $500 \mu \mathrm{g}$ $(0.5 \mathrm{mg})$ of $\mathrm{Cu}$ and nearly $2300 \mu \mathrm{g}(2.3 \mathrm{mg})$ of $\mathrm{Zn}$ per $11 \mathrm{of}$ breast milk on the 30th day of lactation. According to Wasowicz et al. [48], the highest content of $\mathrm{Zn}$ and $\mathrm{Cu}$ is found in colostrum. The present study also demonstrated that the milk of mothers in the first 6 months of lactation contained more $\mathrm{Zn}$ and $\mathrm{Cu}$ than in the second 6 months. A statistical analysis carried out by Rydzewska and Król [49] revealed a correlation between the concentration of $\mathrm{Zn}$ and the day of the postpartum period and increased content of $\mathrm{Zn}$ and reduced level of $\mathrm{Cu}$ in the colostrum. Leotsinidis et al. [46] found that the colostrum of Greek women contained much more $\mathrm{Zn}$ than the post-colostral milk ( 4.9 vs. $2.99 \mathrm{mg} / \mathrm{l})$. However, no significant difference was found in the content of $\mathrm{Cu}$ in the colostrum and the post-colostral milk. A different content of essential trace elements in the colostrum and the post-colostral milk can occur due to genetic conditions of the lactation process [50].

\section{Effects of Women's Age}

According to Rahimi et al. [13] the average concentration of $\mathrm{Cd}$ and $\mathrm{Pb}$ in women aged under 30 years was lower than in women aged over 30 years. In this study, the lowest content of both $\mathrm{Cd}$ and $\mathrm{Pb}$ was characteristic of the milk of women aged 20 to 25 . The present study shows that the age of the women is also a factor affecting the concentration of essential trace elements in milk. Honda et al. [51] show that a woman's age is a factor affecting the concentration of essential trace elements in her breast milk. Picciano [52] found that the breast milk of women over 30 contains more $\mathrm{Zn}$ and $\mathrm{Cu}$ than that of 
Table $6 \mathrm{Cd}, \mathrm{Pb}, \mathrm{Cu}$ and $\mathrm{Zn}$ concentrations in breast milk of women from Poland and from other countries

\begin{tabular}{|c|c|c|c|c|c|}
\hline & $\mathrm{Cd}, \mu \mathrm{g} / \mathrm{l}$ & $\mathrm{Pb}, \mu \mathrm{g} / 1$ & $\mathrm{Cu}, \mathrm{mg} / \mathrm{l}$ & $\mathrm{Zn}, \mathrm{mg} / \mathrm{l}$ & References \\
\hline Poland & $0.21-7.35$ & $0.49-12.0$ & $0.03-0.46$ & $0.04-8.16$ & This study \\
\hline Poland & 5.4 & & & & {$[60]$} \\
\hline Poland & & & $0.27-0.45$ & $1.4-8.2$ & {$[48]$} \\
\hline Slovakia & 0.43 & 4.7 & & & {$[61]$} \\
\hline Sweden & 0.07 & 0.5 & & & {$[62]$} \\
\hline Sweden & $0.028-0.27$ & $0.74-6.4$ & $0.32-0.67$ & $1.24-5.71$ & {$[50]$} \\
\hline Spain & $0.6-11.3$ & $0.1-32.3$ & & & {$[63]$} \\
\hline Austria & & $0.02-11.17$ & & & {$[64]$} \\
\hline Austria & $0.22-0.26$ & & & & {$[65]$} \\
\hline Portugal & & $0.07-4.03$ & $0.33-0.97$ & $0.39-5.09$ & {$[47]$} \\
\hline Croatia & & & $0.27-1.35$ & $0.62-15.0$ & {$[38]$} \\
\hline Greece & 0.19 & 0.48 & 0.38 & 4.90 & [46] \\
\hline Brazil & $1.0-8.0$ & & & & {$[34]$} \\
\hline Nigeria & 9.7 & 8.7 & 0.83 & 0.7 & {$[66]$} \\
\hline Kuwait & & & $0.41-0.71$ & $1.7-3.2$ & [67] \\
\hline Japan & $0.07-1.22$ & & $0.12-0.70$ & $2.73-11.6$ & {$[51]$} \\
\hline Japan & & & 0.35 & 1.45 & {$[68]$} \\
\hline Libya & & & $0.39-0.84$ & $4.95-16.1$ & [39] \\
\hline Iran & $0.62-6.35$ & $3.18-24.67$ & & & {$[13]$} \\
\hline Iran & $0.45-5.87$ & $3.06-19.47$ & & & [69] \\
\hline Iran & & & 0.36 & 2.95 & {$[44]$} \\
\hline Saudi Arabia & 1.73 & 31.67 & 3.10 & & {$[70]$} \\
\hline Guatemala & & & $0.09-0.60$ & $0.47-6.19$ & {$[71]$} \\
\hline China & 0.67 & 40.6 & & & {$[72]$} \\
\hline Italy & $<\mathrm{LOQ}$ & $0.85-1.07$ & $0.35-0.42$ & $0.70-0.90$ & {$[73]$} \\
\hline
\end{tabular}

women under 30. By contrast, Koyashiki et al. [34] and Khaghani et al. [44] found no statistically significant effect of the woman's age on the content of $\mathrm{Zn}$ and $\mathrm{Cu}$.

\section{Effects of Lifestyle}

$\mathrm{Cd}$ and $\mathrm{Pb}$ in breast milk reflected maternal exposure. Nishijo et al. [7] observed a positive correlation between maternal $\mathrm{Cd}$ burden and $\mathrm{Cd}$ concentration in breast milk. Gundacker et al. [6] found a correlation between the content of $\mathrm{Pb}$ in the breast milk of Austrian women and their body weight, duration of pregnancy as well as diet and lifestyle. These authors have found the highest accumulation of $\mathrm{Pb}$ in the milk of women weighing less than $60 \mathrm{~kg}$ and women who gave birth after week 37 of pregnancy. Also the content of this element was significantly higher than in the milk of women who often consumed fish and food supplements.

Smoking had a great influence on the $\mathrm{Pb}$ value in breast milk. The milk of women who have never smoked tobacco contained $1.57 \mu \mathrm{g}$ of $\mathrm{Pb}$, while the milk of currently smoking women-2.4 $\mu \mathrm{g} / \mathrm{l}$ (5). Research by Kwapuliński et al. [53] revealed the highest content of $\mathrm{Cd}$ in the breast milk of active and passive smokers $-0.27 \mu \mathrm{g} / \mathrm{g}$. In the group of non- smokers, the content of $\mathrm{Cd}$ was lower-approximately $0.20 \mu \mathrm{g} / \mathrm{g}$. The present study also showed that the content of $\mathrm{Cd}$ and $\mathrm{Pb}$ in the milk of women who smoked was significantly higher than in non-smokers. According to Rahimi et al. [13], the concentration of $\mathrm{Cd}$ and $\mathrm{Pb}$ in breast milk significantly increased in mothers who were exposed to smoking compared to non-smokers (3.39 vs. $2.12 \mu \mathrm{g} / \mathrm{l}$ of $\mathrm{Cd}$ and 12.22 vs. $9.78 \mu \mathrm{g} / \mathrm{l}$ of $\mathrm{Pb}$ ). The present study showed that the content of $\mathrm{Cd}$ and $\mathrm{Pb}$ in the breast milk of women who smoked tobacco was significantly higher than in non-smoking mothers.

Many researchers found no influence of $\mathrm{Cu}$ and $\mathrm{Zn}$ in the diet on the content of $\mathrm{Cu}$ and $\mathrm{Zn}$ in breast milk [54, 55], while single researchers demonstrated that the level of $\mathrm{Zn}$ slightly increased after receiving $\mathrm{Zn}$ supplements [56]. Domellöf et al. [57] found no correlation between the content of $\mathrm{Cu}$ and $\mathrm{Zn}$ in milk and the mineral status of a woman. On the other hand, however, since breast milk of women from different regions of the world, who due to climatic, economic and cultural differences have different diet routines, contains different amounts of $\mathrm{Zn}$ and $\mathrm{Cu}$ (Table 6), the effect of the diet routine on the content of these essential metals in milk cannot be completely excluded. It is possible that a diet deficient in $\mathrm{Zn}$ and $\mathrm{Cu}$ has 
an influence on the low content of these elements in milk. Hambidge [29] found that Zn deficiency was a problem affecting approximately $50 \%$ of the population. Some authors found that the diet of Polish girls and women is deficient in $\mathrm{Zn}$ [58]. According to Szymelfejnik et al. [59], $50 \%$ of female students are at a high risk of $\mathrm{Zn}$ deficiency and approximately $90 \%$ are likely to have $\mathrm{Cu}$ deficiency.

To sum up, the admissible levels of $\mathrm{Cd}$ and $\mathrm{Pb}$ supply were not exceeded but their content was high, particularly in 6month-old infants (nearly $85 \%$ TWI for Cd, nearly $70 \%$ $\mathrm{BMDL}_{01}$ for $\mathrm{Pb}$ ). It is significant that the analysed milk contained insufficient amounts of $\mathrm{Zn}$ and $\mathrm{Cu}$ compared with an infant's requirements of these elements. The reasons for low levels of these essential metals in breast milk must be carefully reviewed. Perhaps these could be attributed to nutritional mistakes of lactating women. The analysed milk should be regarded as safe for infants; however, as breast milk is the basic food for infants, it must be continuously monitored for the level of toxic and essential metals. Since the lifestyle of lactating women has a direct influence on the content of these elements in breast milk, women should be educated in this respect with particular focus on eliminating tobacco smoking, both by breastfeeding mothers and by their direct environment.

Open Access This article is distributed under the terms of the Creative Commons Attribution License which permits any use, distribution, and reproduction in any medium, provided the original author(s) and the source are credited.

\section{References}

1. WHO (2003) Global strategy for infant and young child feeding. WHO Library Cataloguing-in-Publication Data, Geneva

2. Winiarska-Mieczan A (2009) Assessment of infant exposure to lead and cadmium content in infant formulas. J Elementol 14:573-581

3. Lönnerdal B (2003) Nutritional and physiologic significance of human milk proteins. Am J Clin Nutr 77(Suppl):1537-1543

4. Matson AP, Thrall RS, Rafti E, Lingenheld EG, Puddington L (2010) Research IgG transmitted from allergic mothers decreases allergic sensitization in breastfed offspring. Clin Mol Allergy 8:9. doi:10. 1186/1476-7961-8-9

5. Tong S, Schirnding YE, Prapamontol T (2000) Environmental lead exposure a public health problem of global dimensions. Bull WHO 78:1068-1077

6. Gundacker C, Pietschnig B, Wittmann JK, Lischka A, Salzer H, Hohenauer L, Schuster E (2002) Lead and mercury in breast milk. Pediatrics 110:873-878

7. Nishijo M, Nakagawa H, Honda R, Tanabe K, Saito S, Teranishi K, Tawara K (2002) Effects of maternal exposure to cadmium on pregnancy and breast milk. Occup Environ Med 59:394-397

8. Koizumi N, Murata K, Hayashi C, Nishio H, Goji J (2008) High cadmium accumulation among humans and primates: comparison across mammalian species - a study from Japan. Biol Trace Elem Res 121:205-214

9. Yüzbaşi N, Sezgin E, Yıldırım M, Yıldırım Z (2003) Survey of lead, cadmium, iron, copper and zinc in Kasar cheese. Food Addit Contam, Part A 20:464-469
10. Iwegbue CMA, Nwajei GE, Arimoro FO, Eguavoen O (2009) Characteristic levels of heavy metals in canned sardines consumed in Nigeria. Environment 29:431-435

11. Kot A, Zaręba S, Wyszogrodzka-Koma L (2009) Assessment of cadmium contamination in cereals, cereal products and potatoes. Bromat Chem Toksykol 3:537-542

12. Kutlu T, Karagozler AA, Gozukara EM (2006) Relationship among placental cadmium, lead, zinc, and copper levels in smoking pregnant women. Biol Trace Elem Res 114:7-17

13. Rahimi E, Hashemi M, Torki Baghbadorani Z (2009) Determination of cadmium and lead in human milk. Int J Environ Sci Technol 6: 671-676

14. Öhrvik H, Yoshioka M, Oskarsson A, Tallkvist J (2006) Cadmiuminduced disturbances in lactating mammary glands of mice. Toxicol Lett 3:207-213

15. Duffus JH (2002) "Heavy metals"— a meaningless term? Pure Appl Chem 74:793-807

16. Bradstreet J, Geier DA, Kartzinel JJ, Adams JB, Geier MR (2003) A case-control study of mercury burden in children with autistic spectrum disorders. J Am Phys Surg 3:76-79

17. IARC (1993) Cadmium and cadmium compounds. CAS No. 744043-9. International Agency for Research on Cancer. Monographs. IARC Press, Lyon

18. Silbergeld EK, Waalkes M, Rice JM (2000) Lead as a carcinogen: experimental evidence and mechanisms of action. Am J Ind Med 38: $316-323$

19. Järup L (2003) Hazards of heavy metal contamination. Br Med Bull 68:167-182

20. Sughis M, Penders J, Haufroid V, Nemery B, Nawrot TS (2011) Bone resorption and environmental exposure to cadmium in children: a cross-sectional study. Environ Health 10:104-109

21. Andersson H, Petersson-Grawe K, Lindqvist E, Luthman J, Oskarsson A, Olson L (1997) Low-level cadmium exposure of lactating rats causes alterations in brain serotonin levels in the offspring. Neurotoxicol Teratol 19:105-115

22. Sreedharan R, Mehta DI (2004) Gastrointestinal tract. Pediatrics 113: 1044-1049

23. D'Souza HS, Menezes G, Venkatesh T (2003) Role of essential trace minerals on the absorption of heavy metals with special reference to lead. Ind J Clin Biochem 18:154-160

24. Dietrich KN, Berger OG, Succop PA (1993) Lead exposure and the motor development status of urban six-year-old children in the Cincinnati prospective study. Pediatrics 91:301-307

25. Koller K, Brown T, Spurgeon A, Levy L (2004) Recent developments in low-level lead exposure and intellectual impairment in children. Environ Health Perspect 112:987-994. doi:10.1289/ehp.6941

26. Gulson BL, Jameson CW, Mahaffey KR, Mizon KJ, Patison N, Law AJ, Korsch MJ, Salter MA (1998) Relationships of lead in breast milk to lead in blood, urine and diet of the infant and mother. Environ Health Perspect 106:667-674

27. Soetan KO, Olaiya CO, Oyewole OE (2010) The importance of mineral elements for humans, domestic animals and plants: a review. Afr J Food Sci 4:200-222

28. Wu J, Ricker M, Muench J (2006) Copper deficiency as cause of unexplained hematologic and neurologic deficits in patient with prior gastrointestinal surgery. J Am Board Family Med 19:191-194

29. Hambidge M (2000) Human zinc deficiency. J Nutr 130:1344-1349

30. Książyk J, Weker H (2007) New feeding plan for infants in Poland, since 2007. Pediatr Współcz Gastroenterol Hepatol Żyw Dziecka 9:9-14

31. EFSA (2012) Cadmium dietary exposure in the European population. EFSA J 10:2551-2588

32. EFSA (2012) Lead dietary exposure in the European population. EFSA J 10:2831-2890

33. Jarosz M, Bułhak-Jachymczyk B (2008) Norms of human nutrition: essential of prevention of obesity and non-infectious diseases. PZWL, Warsaw 
34. Koyashiki GAK, Paoliello MMB, Matsuo T, de Oliveira MMB, Mezzaroba L, Carvalho MF, Sakuma AM, Turini C, Vannuchi MTO, Barbosa CSD (2010) Lead levels in milk and blood from donors to the Breast Milk Bank in Southern Brazil. Environ Res 110:265-271

35. Winiarska-Mieczan A, Kiczorowska B (2012) Determining the content of lead and cadmium in baby food from the Polish market. Int $\mathrm{J}$ Food Sci Nutr 63:708-712

36. Dabeka R, Fouquet A, Belisle S, Turcotte S (2011) Lead, cadmium and aluminum in Canadian infant formulae, oral electrolytes and glucose solutions. Food Addit Contam 28:744-753

37. Al Khlifa AS, Ahmad D (2010) Determination of key elements by ICP-OES in commercially available infant formulae and baby foods in Saudi Arabia. Afr J Food Sci 4(7):464-468

38. Mandić Z, Mandić ML, Grgić J, Grgić Z, Klapec T, Primorac L, Hasenay D (1993) Copper and zinc content in human milk in Croatia. Eur J Epidemiol 13:185-188

39. Hannan AM, Dogadkin NN, Ashur AI, Markus MW (2005) Copper, selenium, and zinc concentrations in human milk during the first three weeks of lactation. Biol Trace Elem Res 107:11-20

40. WHO (2003) Feeding and nutrition of infants and young children. Guidelines for the WHO European Region, with emphasis on the former Soviet countries. European Series, No 87. WHO Regional Publication, Copenhagen

41. Donangelo CM, Trugo NMF, Dorea JG (1993) Hepatic reserves of iron, copper and vitamin B12 in Brazilian fetuses and infants of different socioeconomic status. Nutrition 9:430-432

42. Casey CE, Hambidge KM, Neville MC (1985) Studies in human lactation: zinc, copper, manganese and chromium in human milk in the first month of lactation. Am J Clin Nutr 41:1193-1200

43. Lönnerdal B, Bell JG, Keen CL (1985) Copper absorption from human milk, cow's milk, and infant formulas using a suckling rat model. Am J Clin Nutr 42:836-844

44. Khaghani S, Ezzatpanah H, Mazhari N, Givianrad M-H, Mirmiranpour H, Sadrabadi FS (2010) Zinc and copper concentrations in human milk and infant formulas. Iran J Pediat 20:53-57

45. Borkow G, Gabbay J (2005) Copper as a biocidal tool. Curr Med Chem 12:2163-2175

46. Leotsinidis M, Alexopoulos A, Kostopoulou-Farri E (2005) Toxic and essential elements in human milk from Greek lactating women. Association with dietary habits and other factors. Chemosphere 61: 238-247

47. Almeida AA, Lopes MPVC, Silva MSA, Barrado E (2008) Trace elements in human milk; Correlation with blood levels, inter-element correlations and concentration during the first month of lactation. $\mathrm{J}$ Trace Elem Med Biol 22:196-205

48. Wasowicz W, Gromadzinska J, Szram K, Rydzyński K, Cieślak J, Pietrzak Z (2001) Selenium, zinc, and copper concentrations in the blood and milk of lactating women. Biol Trace Elem Res 79:221-233

49. Rydzewska A, Król I (1996) Contents of zinc, copper and cadmium in milk of women living in Poznań. Ginekol Pol 67:125-128

50. Björklund KL, Vahter M, Palm B, Grandér M, Lignell S, Berglund M (2012) Metals and trace element concentrations in breast milk of first time healthy mothers: a biological monitoring study. Environ Health 11:92-99

51. Honda R, Tawara K, Nishijo M, Nakagawa H, Tanebe K, Satio S (2003) Cadmium exposure and trace elements in human breast milk. Toxicology 186:255-259

52. Picciano MF (1998) Human milk: nutritional aspects of a dynamic food. Biol Neonate 74:84-93

53. Kwapuliński J, Wiechuła D, Fischer A (2004) The influence of smoking and passive smoking to occurrence of metals in breast milk. Przegl Lek 61:1113-1115
54. Vuori E, Makinen SM, Kara R, Kuitunen P (1980) The effects of the dietary intakes of copper, iron, manganese, and zinc on the trace element content of human milk. Am J Clin Nutr 33:227-231

55. Lönnerdal B (1986) Effects of maternal dietary intake on human milk composition. J Nutr 116:499-513

56. Krebs NF, Reidinger CJ, Hartley S, Robertson AD, Hambidge KM (1985) Zinc supplementation during lactation: effects on maternal status and milk zinc concentrations. Am J Clin Nutr 61: $1030-1036$

57. Domellöf M, Lönnerdal B, Dewey KG, Cohen RJ, Hernell O (2004) Iron, zinc, and copper concentrations in breast milk are independent of maternal mineral status. Am J Clin Nutr 79:111-115

58. Bojar I, Owoc A, Humeniuk E, Wierzba W, Fronczak A (2012) Inappropriate consumption of vitamins and minerals by pregnant women in Poland. Ann Agric Environ Med 19:263-266

59. Szymelfejnik EJ, Wadolowska L, Cichon R (2008) Magnesium, zinc and copper intake by Polish university students. Pak J Nutr 7:436443

60. Baranowska I (1994) The concentration of some trace elements in human milk. Pol J Environ Stud 3:5-8

61. Ursinyova M, Massanova V (2005) Cadmium, lead and mercury in human milk from Slovakia. Food Addit Contam 22:579-589

62. Palminger Hallen I, Jorhem L, Lagerkvist BJ, Oskarson A (1995) Lead and cadmium levels in human milk and blood. Sci Total Environ 166:149-155

63. Rodriguez Rodriguez EM, Delgado Uretra E, Diaz Romero C (1999) Concentrations of cadmium and lead in different types of milk. $Z$ Lebensm Unters Forsch A 208:162-168

64. Gundacker C, Pietschnig B, Wittmann KJ, Lischka A (2000) Human milk mercury $(\mathrm{Hg})$ and lead $(\mathrm{Pb})$ levels in Vienna. Adv Exp Med Biol 478:387-388

65. Rossipal E, Krachler M (1998) Pattern of trace elements in human milk during the course of lactation. Nutr Res 18:11-24

66. Adesiyan AA, Akiibinu MO, Olisekodiaka MJ, Onuegbu AJ, Adeyeye AD (2011) Concentrations of some biochemical parameters in breast milk of a population of Nigerian nursing mothers using hormonal contraceptives. Pak J Nutr 10:249-253

67. Al-awadi FM, Srikumar TS (2000) Trace-element status in milk and plasma of Kuwaiti and non-Kuwaiti lactating mothers. Nutrition 16: 1069-1073

68. Yamawaki N, Yamada M, Kan-no T, Kojima T, Kaneko T, Yonekubo A (2005) Macronutrient, mineral and trace element composition of breast milk from Japanese women. J Trace Elem Med Biol 19:171181

69. Goudarzi MA, Parsaei P, Navebpour F, Rahimi E (2012) Determination of mercury, cadmium and lead in human milk in Iran. Toxicol Ind Health. doi:10.1177/0748233712445047

70. Al-Saleh I, Shinwari N, Mashhour A (2003) Heavy metal concentrations in the breast milk of Saudi women. Biol Trace Elem Res 96:2137

71. Dhonukshe-Rutten RAM, Vossenaar M, West CE, Schümann K, Bulux J, Solomons NW (2005) Day-to-day variations in iron, zinc and copper in breast milk of guatemalan mothers. J Pediatr Gastroenterol Nutr 40:128-134

72. Liu K-S, Hao J-H, Xu Y-Q, Gu X-Q, Shi J, Dai Ch-F XF, Shen R (2013) Breast milk lead and cadmium levels in suburban areas of Nanjing, China. Chin Med Sci J 28:7-15

73. Abballe A, Ballard TJ, Dellatte E, di Domenico A, Ferri F, Fulgenzi AR, Grisanti G, Iacovella N, Ingelido AM, Malisch R, Miniero R, Porpora MG, Risica S, Ziemacki G, De Felip E (2008) Persistent environmental contaminants in human milk: concentrations and time trends in Italy. Chemosphere 73:220-227 